\title{
The Effect Of Emotional Quotient, Motivation And The Working Environment On Teacher's Performance With Work Communications As A Moderation Variables In SMK PGRI 1 Giri Banyuwangi
}

\author{
M.Hasyim ${ }^{1}$, Muhammad Firdaus ${ }^{2}$, Yuniorita Indah Handayani ${ }^{3}$ \\ Student of STIE Mandala ${ }^{1}$, Lecturer of STIE Mandala ${ }^{2,3}$ \\ Email: mhasyimse@gmail.com¹, muhammadfirdaus2011@gmail.com², yuniorita@stie- \\ mandala.ac.id ${ }^{3}$
}

\begin{abstract}
This study aims to determine the effect of emotional intelligence, motivation and work environment on teacher performance with work communication as moderation at SMK PGRI 1 Giri Banyuwangi. The data analyzed came from 35 teacher respondents in SMK PGRI 1 Giri Banyuwangi. Data analysis tools with multiple linear regression and multiple linear regression moderation variables with the interaction test method (MRA). The results of linear regression indicate that partially Emotional Intelligence has no significant effect on Teacher Performance, Motivation has a significant effect on Teacher Performance and the Work Environment has a significant effect on Teacher Performance. Line 2 linear regression with the addition of the independent variable Work Communication shows that partially Emotional Intelligence has no significant effect on Teacher Performance, Motivation has a significant effect on Teacher Performance, Work Environment has a significant effect on Teacher Performance and Work Communication has no significant effect on Teacher Performance. The results of the moderation regression show that work communication partially moderates the effect of Emotional Intelligence on Teacher Performance, Work Communication moderates the effect of motivation on Teacher Performance and Work Communication moderates weakens the influence of the Work Environment on Teacher Performance.
\end{abstract}

Keywords: Emotional Intelligence, Motivation, Work environment, Work Communication and Teacher Performance.

\section{INTRODUCTION}

The purpose of National Education according to mandate UU no 20 Of 2013 can be realized good student's achievement supported by excellent teacher's performance. There are 
some internal factors influence student's achievement,such as teacher psycologycal factor that consists of intellectual factor, level of teacher's emotional quotient and non-intellectual factor,teacher's teaching habit.Intellectual factor (emotional intellegernce) has obvious effect on achievement of teacher's performance.Someone having high relative emotional Quotient tends to be better than the lower one.But,emotional factor is not the only factor can determine teacher's achievement.Excellent score standard, teaching completeness score nationally standarized must be achieved by the teachers.It also can force teachers to change their teaching habit into better one.

As stated by Daniel Goleman(2000) that performance achievement determined by $20 \%$ Intellegency Quotient, while $80 \%$ by Emotional Quotient and this kind of emotional as stated by Joan Beck (in Mangkunegara,2005) that emotional quotient can be developed in limitless time.Therefore, if a leader wants maximum teacher performance,the exact effort is how to manage him self and the Human Resources of his subordinate to have good emotional quotient.Good emotional quotient means understand others well,having nice identity,mature personality,no envy,not being hated,not being resentful.not in grudge,not being over blameless, not being worried,not being angry easily, not being easily frustated.

During working,teacher motivation getting change as the result of communication intraction among teachers in their working place. If working condition,relationship among teachers,relationship with their superior and official policy are not in accordance with them then their working passion getting down with low performance vise versa.That's not only from intellectul aspect or skill but also from emotional quotient can affects teacher's performance.

In doing daily activities,the surrounding need to be noticed,in this case our working place. Working place has big effect to the running of a good working system in a place including school. Working place is all physical,psycologycal,social factors and networks applied in an organisation and affect the employees, (B.N. Marbun, 2003)

The working place is the environment where employees work in an office or company. This environment is not only a physical place consisting of a table and chairs, cupboards and work equipment, but includes a wider area (Ghozali, 1997).

In the work environment there is also a work relationship between the people in the room, both between colleagues, between subordinates and superiors, even the systems and 
procedures and rules that applied in the place, all of which affect the work environment. Therefore, if management wants to create a pleasant work environment, the arrangement will include physical space, work equipment, systems, work rules and procedures that must be established so that it can generate enthusiasm for employees.

Teachers are social creatures. As stated in the Republic of Indonesia Law Number 20 of 2003 concerning SISDIKNAS Article 30 Paragraph 2 states "Educators are professionals who are tasked with educating and carrying out the learning process, conducting guidance and training as well as conducting research and community service. He can only live, develop, and play a human role by relating and cooperate with other teachers. One of the most important ways to connect and collaborate with other teachers is communication. Good communication among teachers or with school leaders (school principals). Therefore, communication is an absolute thing in our life with other people. Without communication, we and others cannot connect and exchange thoughts, feelings and desires. To what extent is the importance of communication in a teacher's social life, we can see how he socializes in his environment, one of which is at work, namely school. How teachers communicate with the principal or with fellow teachers is what is called internal communication.

The objectives to be achieved in this study were to test and analyze the influence of Emotional Quotient, Motivation and Work Environment on Teacher Performance at SMK PGRI 1 Giri Banyuwangi. As well as testing and analyzing the role of Work Communication in moderating the influence of Emotional Quotient, Motivation and Work Environment on teacher performance at SMK PGRI 1 Giri Banyuwangi.

Considering the many developments that can be found in this problem, it is necessary to have clear problem boundaries regarding what is made and resolved in this study. The number of factors that are thought to affect teacher performance, so in this study will be limited to: Emotional Quotient, Motivation, Work Environment and Teacher Performance with Work Communication as a moderating variable.

\section{RESEARCH METHODS}

The location of this research is at SMK PGRI 1 Giri Banyuwangi. The number of students in the 2019-2020 school year was 1,206 students with 60 teachers. Competency skills have been opened until the 2019-2020 school year are: Office Governance Automation (OTKP), 
Accounting and Financial Institutions (AKL), Online Business and Marketing (BDP), Computer and Network Engineering (TKJ) and Restaurant (TB) departments . When the research was carried out in December and January, the 2019-2020 school year.

The population are 60 teachers of SMK PGRI The sampling method that will be used is purposive sampling, using criteria that the researcher has chosen himself in selecting the sample. The criteria chosen were teachers who taught at SMK PGRI 1 Giri Banyuwangi with a total sample of 35 teachers. 1 Giri Banyuwangi in the academic year 2019-2020.

The population in this study were 60 teachers of SMK PGRI 1 Giri Banyuwangi, consisting of 27 Permanent Foundation Teachers (GTY), 18 Permanent Pure Teachers (GTM) and 15 PNS Non-Permanent Teachers (GTT PNS), all of whom met the requirements. in the inclusion criteria in sample selection. Furthermore, the researcher will determine the number of samples using special criteria, namely exclusion criteria. The basis for the exclusion criteria that will be used is teachers who only teach at SMK PGRI 1 Giri Banyuwangi and do not teach at other schools with the aim and hope of being more effective and efficient in the process of collecting sample data. Based on the exclusion criteria, the number of samples to be used in this study were 35 teachers consisting of 27 Permanent Foundation Teachers (GTY) and 18 Permanent Pure Teachers (GTM).

The variables to be analyzed in this study are classified into three types of variables:

\section{a. Independent Variable}

This variable is often referred to as the stimulus, predictor, and antecedent variable. Or called the independent variable, which is a variable that affects or causes the change or the emergence of the dependent variable (dependent) (Sugiyono, 2009).

The independent variables in this study are Emotional Quotient (X1), Motivation (X2) and Work Environment (X3).

\section{b. Dependent Variable}

The dependent variable in this study is Teacher Performance (Y).

\section{c. Moderation Variables}

The moderating variable in this study is Work Communication $(\mathrm{Z})$.

Based on existing theoretical foundations, the authors feel the need to develop a variable operational concept. The operational definition of the variables in this study are as follows: 


\section{Dependent Variable}

The dependent variable in this study is performance (Y). Teacher performance is the ability: (quality) of a person to complete a job, (quantity) of the amount produced, timeliness, price effectiveness, supervision, and interpersonal relationships.

Performance variables are measured by indicators, such as: quality of work results, quantity of work results, timeliness of work results and work effectiveness.

\section{Independent Variable}

\section{a. Emotional Intelligence (X1)}

Emotional qutient is a person's ability to self-awareness, self-regulation, empathy and social skills.

Emotional quotient variables are measured by indicators, such as: self-awareness, selfregulatio.

\section{b. Motivation (X2)}

According to Hadari Nawawi (2007), work motivation is a condition that encourages or causes a person to do an action / activity that happens place consciously.

Motivation variables are measured by indicators, such as: morale, work performance, cooperation, a conducive work atmosphere and responsibility for the assigned tasks and empathy.

\section{c. Work Environment (X3)}

The work environment is the social, psychological, and physical life in the company that affects workers in carrying out their duties.

Work environment variables are measured by indicators according to Sedarmayanti (2001), are:

1. Physical work environment consisting of : lighting in the work space, air circulation in the work space, noise, use of color, humidity and facilities.

2. Non-physical work environment indicators which consist of: harmonious relationships, opportunities for advancement and safety in work.

\section{Variable Moderation $(\mathrm{Z})$}

\section{a. Work communication}


According to Everett M. Rogers, communication is a process where an idea is transferred from a source to a recipient or more, with the purpose of changing their behavior (Hafied Cangara, 1998)

Work communication moderation variables are measured by indicators according to Suranto AW (2007), are: Understanding, Pleasure, Attitudes, Relationships, Actions and Communication Processes.

Collecting data in this study using 5 ways, are: questionnaires, interviews, observation, document study and literature study.

After the data is obtained using data collection techniques as described above, the data will be processed with the following analysis stages:

1. Validity Test.

2. Reliability Test.

3. Classic Assumption Test, which consists of :

3.1 Normality Test.

3.2 Heteroscedasticity Test.

3.3 Multicollinearity Test.

3.4 Multiple Linear Regression.

4. Hypothesis Testing, which consists of :

4.1 Statistical test $\mathrm{t}$.

4.2 Moderated Variable Regression Test using MRA.

5. The coefficient of determination ( $\mathrm{R}$ Square). 


\section{RESULT AND DISCUSSION}

Analysis Of Study Results

\section{Multiple Linear Regression Test Results}

\section{Coefficients $^{\mathrm{a}}$}

\begin{tabular}{|c|c|c|c|c|c|c|}
\hline \multicolumn{2}{|r|}{ Model } & \multicolumn{2}{|c|}{ Unstandardized Coefficients } & \multirow{2}{*}{$\begin{array}{c}\begin{array}{c}\text { Standardized } \\
\text { Coefficients }\end{array} \\
\text { Beta }\end{array}$} & \multirow[t]{2}{*}{$\mathbf{t}$} & \multirow[t]{2}{*}{ Sig. } \\
\hline & & $\mathbf{B}$ & Std. Error & & & \\
\hline \multirow{4}{*}{1} & (Constant) & 17,679 & 7,462 & & 2,369 & ,024 \\
\hline & EQ & 112 & 193 & ,089 &, 578 & ,567 \\
\hline & Motivation & ,527 &, 187 & ,435 & 2,816 & ,008 \\
\hline & Environtment & ,329 & , 136 & ,352 & 2,415 & ,022 \\
\hline
\end{tabular}

a. Dependent Variable: PERFORMANCE

\subsection{Testing the Emotional Quotient Variable Regression Coefficient (X1)}

Obtained the value of $\mathrm{t}$ count of 0.578 . The $\mathrm{t}$ distribution table is sought at $\mathrm{a}=5 \%: 2=$ $2.5 \%$ (2-tailed test) with degrees of freedom (df) nk-1 or 35-3-1 = 31 ( $\mathrm{n}$ is the number of cases and $\mathrm{k}$ is the number of independent variables). With a 2 -sided test (significance $=0.025$ ) the results obtained for the t table are 2.0395. The testing criteria is Ho is accepted if $-\mathrm{t}$ table $<\mathrm{t}$ count $<\mathrm{t}$ table and Ho is rejected if - $\mathrm{t}$ count $<-\mathrm{t}$ table or $\mathrm{t}$ count $>$ table. Because the value of $\mathrm{t}$ count $<\mathrm{t}$ table $(0.5378<2.0395)$ then Ho is accepted, meaning that partially there is no significant influence between Emotional Quotient and Teacher Performance. So it can be concluded that partially Emotional Quotient has no significant effect on Teacher Performance at SMK PGRI 1 Giri Banyuwangi.

From the results of testing the moderation regression coefficient, the interaction between the Emotional Quotient variable (X1) and the Work Communication variable (Z), the results of the H4 hypothesis test which states that Work Communication moderates the effect of Emotional Intelligence on the Teacher Performance of SMK PGRI 1 Giri Banyuwangi is not proven.

\subsection{Testing the Motivation Variable Regression Coefficient (X2)}

Obtained the $t$ value of 2.816 . The $t$ distribution table is sought at $a=5 \%: 2=2.5 \%$ (2tailed test) with degrees of freedom (df) nk-1 or 35-3-1 = 31 ( $\mathrm{n}$ is the number of cases and $\mathrm{k}$ is the number of independent variables). With a 2 -sided test (significance $=0.025$ ) the results 
obtained for the $\mathrm{t}$ table are 2.0395. The testing criteria is Ho is accepted if $-\mathrm{t}$ table $<\mathrm{t}$ count $<\mathrm{t}$ table and Ho is rejected if $-\mathrm{t}$ count <-t table or $\mathrm{t}$ count $>$ table. The value of $\mathrm{t}$ count $>\mathrm{t}$ table $(2.816>2.0395)$ then Ho is rejected. Because the value of $t$ count $>t$ table $(2.816>2.0395)$ then Ho is rejected, meaning that partially there is a significant influence between motivation and teacher performance. So it can be concluded that partially motivation has a significant effect on teacher performance at SMK PGRI 1 Giri Banyuwangi.

From the results of testing the regression coefficient of the Motivation variable (X2), the results of the $\mathrm{H} 2$ hypothesis test which states that motivation has a significant effect on the Teacher Performance of SMK PGRI 1 Giri Banyuwangi is proven.

\subsection{Testing the Work Environment Variable Regression Coefficient (X3)}

Obtained the $t$ value of 2.415. The $t$ distribution table is sought at $a=5 \%: 2=2.5 \%$ (2tailed test) with degrees of freedom (df) nk-1 or 35-3-1 = 31 ( $\mathrm{n}$ is the number of cases and $\mathrm{k}$ is the number of independent variables). With a 2-sided test (significance $=0.025$ ) the results obtained for the $\mathrm{t}$ table are 2.0395. The testing criteria is Ho is accepted if $-\mathrm{t}$ table $<\mathrm{t}$ count $<\mathrm{t}$ table and Ho is rejected if $-t$ count <-t table or $t$ count $>$ table. The value of $t$ count $>t$ table $(2.415>2.0395)$ then Ho is rejected. Because the value of $t$ count $>t$ table $(2.415>2.0395)$ then Ho is rejected, meaning that partially there is a significant influence between the work environment and teacher performance. So it can be concluded that partially the work environment has a significant effect on teacher performance at SMK PGRI 1 Giri Banyuwangi.

From the results of the regression coefficient test for Path 2 Work Environment variable (X3), the results of the $\mathrm{H} 3$ hypothesis test which states that the Work Environment has a significant effect on the Teacher Performance of SMK PGRI 1 Giri Banyuwangi is proven. 


\section{Multiple Linear Regression Test Results Path 2}

\section{Coefficients $^{\mathrm{a}}$}

\begin{tabular}{|c|c|c|c|c|c|c|}
\hline \multirow{2}{*}{\multicolumn{2}{|c|}{ Model }} & \multicolumn{2}{|c|}{$\begin{array}{c}\text { Unstandardized } \\
\text { Coefficients }\end{array}$} & $\begin{array}{l}\text { Standardized } \\
\text { Coefficients }\end{array}$ & \multirow[t]{2}{*}{$\mathbf{t}$} & \multirow[t]{2}{*}{ Sig. } \\
\hline & & B & Std. Error & Beta & & \\
\hline \multirow{5}{*}{1} & (Constant) & 21,318 & 8,369 & & 2,547 & ,016 \\
\hline & EQ & ,106 & ,193 &, 085 & 550 & ,586 \\
\hline & MOTIVATION & ,526 & ,187 & ,434 & 2,804 & 009 \\
\hline & ENVIRONTMENT & 340 & ,137 & ,363 & 2,483 &, 019 \\
\hline & COMMUNICATION & \begin{tabular}{|c|}
,- 102 \\
\end{tabular} & ,106 &,- 117 &,- 964 & ,343 \\
\hline
\end{tabular}

a. Dependent Variable: PERFORMANCE

\subsection{Testing the Path 2 Regression Coefficient for Emotional Intelligence Variables (X1)}

Obtained the value of $\mathrm{t}$ count of 0.085 . The $\mathrm{t}$ distribution table is sought at $\mathrm{a}=5 \%: 2=2.5 \%$ (2-tailed test) with degrees of freedom (df) nk-1 or 35-4-1 = 30 ( $\mathrm{n}$ is the number of cases and $\mathrm{k}$ is the number of independent variables). With a 2-sided test (significance $=0.025$ ) the results obtained for the $\mathrm{t}$ table are 2.0423. The test criterion is Ho is accepted if $-\mathrm{t}$ table $<\mathrm{t}$ count $<\mathrm{t}$ table and Ho is rejected if - $t$ count <-t table or $t$ count $>$ table. The value of $t$ count $<\mathrm{t}$ table $(0.085$ $<2.0423)$ then Ho is accepted. Because the value of $t$ count $<t$ table $(0.085<2.0423)$, Ho is accepted, meaning that partially there is no significant influence between Emotional Intelligence and Teacher Performance. So it can be concluded that partially Emotional Intelligence has no significant effect on Teacher Performance at SMK PGRI 1 Giri Banyuwangi.

From the test results of the regression coefficient path 2 variable Emotional Intelligence (X1), the results of the $\mathrm{H} 1$ hypothesis test which states that Emotional Intelligence has a significant effect on the Teacher Performance of SMK PGRI 1 Giri Banyuwangi is not proven.

\subsection{Testing of Path 2 Regression Coefficient for Motivation Variables (X2)}

Obtained the $t$ value of 2.804 . The $t$ distribution table is sought at $a=5 \%: 2=2.5 \%$ (2tailed test) with degrees of freedom (df) nk-1 or 35-4-1 = 30 ( $\mathrm{n}$ is the number of cases and $\mathrm{k}$ is the number of independent variables). With a 2 -sided test (significance $=0.025$ ) the results obtained for the $\mathrm{t}$ table are 2.0423. The test criterion is Ho is accepted if $-\mathrm{t}$ table $<\mathrm{t}$ count $<\mathrm{t}$ table and Ho is rejected if $-\mathrm{t}$ count <-t table or $\mathrm{t}$ count $>$ table. The value of $\mathrm{t}$ count $>\mathrm{t}$ table $(2.084>2.0423)$ then Ho is rejected. Because the value of $t$ count $>t$ table $(2.084>2.0423)$ then Ho is rejected, meaning that partially there is a significant influence between motivation and teacher performance. So it can be concluded that partially motivation has a significant effect on teacher performance at SMK PGRI 1 Giri Banyuwangi. 
From the results of testing the regression coefficient (path 2) of the Motivation variable (X2), the results of the $\mathrm{H} 2$ hypothesis test which states that motivation has a significant effect on the Teacher Performance of SMK PGRI 1 Giri Banyuwangi is proven.

\subsection{Testing of Path 2 Regression Coefficient of Work Environment Variable (X3)}

Obtained $\mathrm{t}$ value of 2.483 . The $\mathrm{t}$ distribution table is sought at a $=5 \%: 2=2.5 \%$ (2-tailed test) with degrees of freedom ( $\mathrm{df}$ ) nk-1 or $35-4-1=30$ ( $\mathrm{n}$ is the number of cases and $\mathrm{k}$ is the number of independent variables). With a 2-sided test (significance $=0.025$ ) the results obtained for the $\mathrm{t}$ table are 2.0423. The test criterion is Ho is accepted if $-\mathrm{t}$ table $<\mathrm{t}$ count $<\mathrm{t}$ table and Ho is rejected if - $t$ count <-t table or $t$ count $>$ table. The value of $t$ count $>t$ table $(2.483>2.0423)$ then Ho is rejected. Because the value of $t$ count $>t$ table $(2.483>2.0423)$ then Ho is rejected, meaning that partially there is a significant influence between the work environment and teacher performance. So it can be concluded that partially the work environment has a significant effect on teacher performance at SMK PGRI 1 Giri Banyuwangi.

From the results of the regression coefficient test for Path 2 Work Environment variable (X3), the results of the $\mathrm{H} 3$ hypothesis test which states that the Work Environment has a significant effect on the Teacher Performance of SMK PGRI 1 Giri Banyuwangi is proven.

\subsection{Testing Path 2 Regression Coefficient Work Communication Variable (Z)}

Obtained the value of $\mathrm{t}$ count of -0.017 . The $\mathrm{t}$ distribution table is sought at $\mathrm{a}=5 \%: 2=$ $2.5 \%$ (2-tailed test) with degrees of freedom (df) nk-1 or 35-4-1 $=30$ ( $\mathrm{n}$ is the number of cases and $\mathrm{k}$ is the number of independent variables). With a 2 -sided test (significance $=0.025$ ) the results obtained for the $\mathrm{t}$ table are 2.0423. The test criterion is Ho is accepted if $-\mathrm{t}$ table $<\mathrm{t}$ count $<\mathrm{t}$ table and Ho is rejected if - $\mathrm{t}$ count $<-\mathrm{t}$ table or $\mathrm{t}$ count $>$ table. The value of $\mathrm{t}$ count $<\mathrm{t}$ table $(-$ $0.017<2.0423)$ then Ho is accepted. Because the value of $t$ count $<$ t table $(-0.017<2.0423)$, Ho is accepted, meaning that partially there is no significant influence between work

communication and teacher performance. So it can be concluded that partially Work Communication has no significant effect on Teacher Performance at SMK PGRI 1 Giri Banyuwangi. 


\section{Multiple Linear Regression Test Results With Moderated Variables (MRA Method)}

\section{Coefficients $^{\mathrm{a}}$}

\begin{tabular}{|c|c|c|c|c|c|c|}
\hline \multirow{2}{*}{\multicolumn{2}{|c|}{ Model }} & \multicolumn{2}{|c|}{$\begin{array}{c}\text { Unstandardized } \\
\text { Coefficients }\end{array}$} & $\begin{array}{c}\text { Standardized } \\
\text { Coefficients }\end{array}$ & \multirow[t]{2}{*}{$\mathbf{t}$} & \multirow[t]{2}{*}{ Sig. } \\
\hline & & B & Std. Error & Beta & & \\
\hline \multirow{8}{*}{1} & (Constant) & 38,692 & 55,156 & & ,701 & ,489 \\
\hline & EQ &,- 161 & 1,442 &,- 129 &,- 112 & ,912 \\
\hline & MOTIVATION &,- 189 & 1,873 &,- 156 &,- 101 & ,920 \\
\hline & ENVIRONTMENT & ,973 & 1,432 & 1,039 & ,679 & ,503 \\
\hline & COMMUNICATION &,- 534 & 1,424 &,- 611 &,- 375 & ,711 \\
\hline & EQCOM & ,006 & ,038 & ,333 & , 166 & ,869 \\
\hline & MOTCOM & ,018 & ,049 & 1,214 & 377 & ,709 \\
\hline & ENVICOM &,- 016 & ,037 & $-1,092$ &,- 441 & ,663 \\
\hline
\end{tabular}

a. Dependent Variable: Performance

\subsection{Testing the Moderation Regression Coefficient of the Interaction of the Emotional Quotient Variable (X1) with the Work Communication Variable (Z)}

Obtained $t$ value of 0.166 . The $t$ distribution table is sought at a $=5 \%: 2=2.5 \%$ (2-tailed test) with degrees of freedom (df) nk-1 or 35-4-1 = 30 ( $\mathrm{n}$ is the number of cases and $\mathrm{k}$ is the number of independent variables). With a 2-sided test (significance $=0.025$ ) the results obtained for the $\mathrm{t}$ table are 2.0518. The test criterion is Ho is accepted if $-\mathrm{t}$ table $<\mathrm{t}$ count $<\mathrm{t}$ table and Ho is rejected if $-\mathrm{t}$ count $<-\mathrm{t}$ table or $\mathrm{t}$ count $>$ table. The value of $\mathrm{t}$ count $<\mathrm{t}$ table $(0.085$ $<2.0423)$ then Ho is accepted. Because the value of $t$ count $<\mathrm{t}$ table $(0.166<2.0518)$ then Ho is accepted, meaning that partially Work Communication does not moderate the effect of Emotional Quotient on Teacher Performance. So it can be concluded that partially Work Communication does not moderate the influence of Emotional Quotient on Teacher Performance at SMK PGRI 1 Giri Banyuwangi.

From the results of testing the moderation regression coefficient, the interaction between the Emotional Intelligence variable (X1) and the Work Communication variable (Z), the results of the $\mathrm{H} 4$ hypothesis test which states that Work Communication moderates the effect of Emotional Quotient on the Teacher Performance of SMK PGRI 1 Giri Banyuwangi is not proven. 


\subsection{Testing the Moderation Regression Coefficient for the Interaction of Motivation Variables (X2) with Work Communication Variables (Z)}

Obtained the $\mathrm{t}$ value of 0.377 . The $\mathrm{t}$ distribution table is sought at $\mathrm{a}=5 \%: 2=2.5 \%$ (2tailed test) with degrees of freedom (df) nk-1 or 35-4-1 = 30 ( $\mathrm{n}$ is the number of cases and $\mathrm{k}$ is the number of independent variables). With a 2 -sided test (significance $=0.025$ ) the results obtained for the $\mathrm{t}$ table are 2.0518. The test criterion is Ho is accepted if $-\mathrm{t}$ table $<\mathrm{t}$ count $<\mathrm{t}$ table and Ho is rejected if $-\mathrm{t}$ count $<-t$ table or $t$ count $>$ table. The value of $t$ count $<t$ table $(0.085$ $<2.0423)$ then Ho is accepted. Because the value of $t$ count $<\mathrm{t}$ table $(0.377<2.0518)$, Ho is accepted, meaning that partially Work Communication does not moderate the effect of motivation on teacher performance. So it can be concluded that partially work communication does not moderate the influence of motivation on teacher performance at SMK PGRI 1 Giri Banyuwangi.

From the results of testing the moderation regression coefficient, the interaction between the Motivation variable (X2) and the Work Communication variable (Z), the results of the H5 hypothesis test which states that Work Communication moderates the effect of motivation on the Teacher Performance of SMK PGRI 1 Giri Banyuwangi is not proven.

\subsection{Testing the Moderation Regression Coefficient for the Interaction of Work Environment Variables (X3) with Work Communication Variables (Z)}

Obtained the $t$ value of -0.441 . The $t$ distribution table is sought at $a=5 \%: 2=2.5 \%$ (2tailed test) with degrees of freedom (df) nk-1 or 35-4-1 = 30 ( $\mathrm{n}$ is the number of cases and $\mathrm{k}$ is the number of independent variables). With a 2-sided test (significance $=0.025$ ) the results obtained for the $\mathrm{t}$ table are 2.0518. The test criterion is Ho is accepted if $-\mathrm{t}$ table $<\mathrm{t}$ count $<\mathrm{t}$ table and Ho is rejected if $-\mathrm{t}$ count $<-\mathrm{t}$ table or $\mathrm{t}$ count $>$ table. The value of $\mathrm{t}$ count $<\mathrm{t}$ table $(-$ $0.441<2.0423)$ then $\mathrm{Ho}$ is accepted. Because the value of $\mathrm{t}$ count $<\mathrm{t}$ table $(-0.441<2.0518)$ then Ho is accepted, meaning that partially Work Communication does not moderate the influence of the Work Environment on Teacher Performance. So it can be concluded that partially Work Communication does not moderate the influence of the Work Environment on Teacher Performance at SMK PGRI 1 Giri Banyuwangi.

From the results of testing the moderation regression coefficient, the interaction between the Work Environment variable (X3) and the Work Communication variable (Z), the results of the H6 hypothesis test which states that Work Communication moderates the influence of the 
Work Environment on the Teacher Performance of SMK PGRI 1 Giri Banyuwangi is not proven.

To test the existence of the moderating variable Work Communication $(\mathrm{Z})$ as pure moderator, quasi moderator, moderator homologizer or non-moderator variables in this study as shown in the following table:

\begin{tabular}{|c|l|c|c|c|}
\hline No & \multicolumn{1}{|c|}{ Variabel } & Output 2 & Output 3 & Kesimpulan \\
\hline 1. & Emotional Quotient $(\mathrm{X} 1)$ & Not significant & Not significant & Homologizer Moderator \\
\hline 2. & Motivation $(\mathrm{X} 2)$ & Significant & Not significant & $\begin{array}{c}\text { Not Moderator } \\
\text { Quasi Moderator }\end{array}$ \\
\hline 3. & Work Environtment (X3) & Significant & Not significant & $\begin{array}{c}\text { Not Moderator } \\
\text { Quasi Moderator }\end{array}$ \\
\hline
\end{tabular}

\section{INTERPRETATION}

1. Based on the results of data analysis and hypothesis 1 (H1) testing of this study, it is stated that the Emotional Intelligence variable (X1) does not have a significant effect on Teacher Performance (Y). It was concluded that each person has different personality types and ways of showing their emotions, emotionally Quotient people are not only intellectually intelligent but can also build and recognize other people, so that their presence can solve problems instead of creating new problems. Emotional Quotient (EQ) can be trained and developed depending on whether we want to change it or not. If we want to be accepted by society or colleagues, then we must play a social role and behave appropriately towards others.

2. Based on the results of data analysis and hypothesis testing $2(\mathrm{H} 2)$ in this study, it shows that the motivation variable (X2) has a significant effect on teacher performance (Y). Motivated teachers tend to be more productive than non-motivated teachers. Many school institutions admit that it is difficult to motivate their teachers, but this is easier said than done. Every teacher has their own preferences and needs, so they also have different motivations from each other in carrying out their duties and responsibilities.

3. Based on the results of data analysis and hypothesis testing $3(\mathrm{H} 3)$ in this study, it shows that the Work Environment variable (X3) has a significant effect on Teacher Performance (Y). A working environment condition is said to be good or appropriate if the people in it can carry out their activities optimally, healthy, safe and comfortable. The suitability of the work environment can have an impact for a long time, as well as a bad work environment which will make it difficult to obtain an effective and efficient work system. 
4. Based on the results of data analysis and hypothesis testing 4,5 and 6 (H4, H5 and H6) in this study, it shows that the Work Communication variable $(Z)$ does not moderate the influence of Emotional Quotient (X1), Motivation (X2) and the Work Environment. (X3) on Teacher Performance (Y). Work communication is the most important factor in work, especially in educational institutions or schools. In working, of course the teachers will always communicate with each other, both with the leadership and with colleagues so that there is no confusion of information and miscommunication. It will be a very serious problem if work communication has no effect on improving teacher performance in schools. And this is what happened at SMK PGRI 1 Giri Banyuwangi.

\section{CONCLUSION}

1. Motivation variable (X2) and work environment (X3) partially have a significant effect on teacher performance $(\mathrm{Y})$. This means that the better the quality of the two variables, the better the teacher performance $(\mathrm{Y})$.

2. Emotional Intelligence variable (X1) has no significant effect on teacher performance (Y).

This means that no matter how high or low the value of Emotional Intelligence (X1) will not affect teacher performance (Y).

3. Work Communication $(\mathrm{Z})$ as a moderating variable does not moderate or weaken the influence of the Emotional Intelligence (X1), Motivation (X2) and Work Environment (X3) variables on Teacher Performance (Y) at SMK PGRI 1 Giri Banyuwangi. This proves that Work Communication $(\mathrm{Z})$ which consists of vertical, horizontal and diagonal communication is still not running well and optimally. So that it cannot strengthen the positive influence of other variables on Teacher Performance (Y).

The results showed that the motivation variable (X2) had the most significant effect compared to other variables, namely Emotional Quotient (X1) and Work Environment (X3).

The Work Communication Variable $(\mathrm{Z})$ as a moderating variable does not moderate or weaken the influence of the Emotional Quotient (X1), Motivation (X2) and Work Environment (X3) variables on Teacher Performance (Y). This negative influence must be immediately overcome and a solution sought by the school manager (management) so that Teacher Performance (Y) can be more optimal and increase. For this reason, special efforts are needed that can be made by school managers, especially school principals, as follows: 
1. To improve teacher performance, among others:

a. Accept teacher attendance well.

b. Giving teacher teaching assignments in accordance with the fields and competencies mastered by the teacher.

c. Forming and implementing subject teacher working groups and subject teacher discussion.

2. To maintain and increase teacher work motivation, among others:

a. Providing incentives and rewards.

b. Show confidence in each teacher.

c. Describe the vision and mission of the school into the vision and mission of each teacher.

d. Provide clear goals for each teacher to achieve.

e. Spread positive energy in the school environment.

f. Transparent in school management.

g. Work and life balance.

3. How to communicate effectively in the work environment can be done by:
a. Always on hand.
b. Friendly.
c. Be a good listener.
d. Convey messages clearly.
e. Be careful with nonverbal language.
f. Be open to feed backs.
g. Open minded.

\section{REFERENCES}

BN Marbun, 2003, Kamus Manajemen, Jakarta:Pustaka Sinar Harapan.

Goleman, Daniel, 2000, Kecerdasan Emosional : Mengapa EI Lebih Penting Dari Pada IQ Jakarta, Gramedia Pustaka Utama.

Gozali, Imam, 2011, Aplikasi Analisis Multivariate Dengan Program SPSS, Semarang:Badan Penerbit Universitas Diponegoro.

Nawawi, Hadari, 2007, Manajemen Sumber Daya Manusia : Untuk Bisnis Yang Kompetitif, Yogyakarta, Gajah Mada University Press. 
Mangkunegara, Anwar, Prabu, 2005, Evaluasi Kinerja SDM, Bandung, Penerbit PT. Refika Aditama.

Sedarmayanti, 2001, Sumber Daya Manusia dan Produktifitas Kerja, Bandung.

Sugiyono, 2009, Metode Penelitian Pendekatan Kuantitatif, Bandung Alfabeta.

Suranto AW, 2007, Komunikasi Efektif Untuk Mendukung Kinerja Perkantoran, UNY, Yogyakarta 